\title{
Book review of Sustainable Land Management in Greater Central Asia: An Integrated and Regional Perspective edited by Victor R. Squires and Lu Qi
}

\author{
John E. Leake®
}

\author{
Book details \\ Victor Squires and Lu Qi \\ Sustainable Land Management in Greater Central Asia: An Integrated and Regional Perspective \\ Abingdon: Routledge; 2018 \\ xxiv 310, ISBN: 1-138-93216-6 (hbk), ISBN:978-315-67939-6 (ebk)
}

Keywords: Greater Central Asia, Rangeland Management, Sustainable Land Management, Land Degradation Neutrality, Socio-ecological Research

Greater Central Asia is a region defined more by climate, trade and cultural identification than genes. Land use has long been a tension between pastoralists moving in response to climate and agriculturalists bound to oases and the major rivers. This book is intended as a contribution to the management of the physical landscapes that are evolving following the collapse of the Soviet Union, the rise of new independent states and renewed Chinese interest in the region's resources and political stability. Although the condition of soils, water and bio-diversity underpins the origin and emphasis of the book, it is the region's strategic location that will dictate investment, so the book is wider in scope than otherwise might be expected.

The book is a culmination of the principal editor's involvement as author or editor of more than ten books on different aspects of rangeland management in the region over a decade. The writings result from practical development experience and academic collaboration in each of the Greater Central Asia (GCA) countries ${ }^{1}$ over more than twenty years. This has connected him with a wide range of authors, investigators and practitioners from each

Correspondence: john.leake@gmail.com

University of Adelaide \& Institute for International Development, Hackney, South Australia, Australia

(c) The Author(s). 2018 Open Access This article is distributed under the terms of the Creative Commons Attribution 4.0 International License (http://creativecommons.org/licenses/by/4.0/), which permits unrestricted use, distribution, and reproduction in any medium, provided you give appropriate credit to the original author(s) and the source, provide a link to the Creative Commons license, and indicate if changes were made. of these countries, plus Iran and India, and their participation greatly adds to the authority of this synthesis.

The book is organised as five parts containing specialist chapters that deal with aspects of each part: (I) covers the background, history, climate and cultural and ethnic diversity that collectively set the complexity of the region, (II) focusses on sustainable land management (SLM), the resources being sustained, the prospects of achieving land degradation neutrality (LDN), and the barriers to this, (III) describes the nature and extent of land degradation using remote sensed data, geographical information system (GIS) maps and other technologies; the role of inter-regional cooperation and multi-lateral donors in attempts at arresting and reversing land degradation is outlined, (IV) addresses the geophysical issues related to SLM in GCA; water, the impact of high mountains on precipitation, and the glaciers that govern water availability. (V) covers the geopolitical factors of what is a now a new world frontier. The roles of China, Russia and other actors are explored in a final synthesis chapter. This chapter provides an agenda for future social-ecological research in each technical area and at each institutional level, including necessary devolution of authority after some 100 years of centralised systems that have left the inhabitants with little means to influence their future. 
The book's strength stems from the experience of its authors and resulting access to very hard-to-find information, including from the Soviet period. Its weakness is the lack of a roadmap to guide necessary investment, except in socio-ecological research which, although clearly essential, is insufficient to induce investment on the scale needed. While the book is an organic whole clearly illustrating the linkages between each subject and activities to achieve SLM, each chapter is self-contained.

Part I defines the extent of GCA, including the five Central Asian 'stans', , and discusses the climatic imperatives of its two production systems, (i) pastoral and (ii) settled oases that evolved between the moisture blocking Tibetan Plateau, which restricts tropical influences and the arctic where plant life gradually tapers off. Important to the theme of the book, this part convincingly shows just how pervasive Soviet collapse has been and how much evolution of new national consensuses are needed before effective socio-economic production systems can evolve. It discusses the need to see the production systems of irrigated agriculture and pastoralism as separate but complimentary activities that pay attention to the old climate imperatives, emerging new climate pressures, and the different cultural traditions of agriculture and livestock.

Part I also provides examples to illustrate why the authors propose new socio-ecological research as a next step, and why new research needs to involve rural communities to better inform this evolution. A most significant conclusion is the extraordinary rates of change being experienced in all of these states for the main indicators of resource decline, due to unsustainable land use practices.

Part II examines resource sustainability for GCA at different scales: time frames, scope of costs and benefits, and levels of society where change is needed. This analysis assists the reader to see the formidable changes in resource management in the GCA that are needed to support the benefits now hoped for. This section describes the barriers to achieving SLM for the two main land use systems: (i) the rangelands, 260 million ha, and (ii) the irrigated lands totalling only eight million ha, but supporting $75 \%$ of the population in the five 'stans'.

A Land Degradation Problem Tree provides a conceptual framework that helps to explain the barriers and linkages to adoption of SLM, most significantly institutional, knowledge, and technological and economic capacities. Changes in attitudes are occurring but change agents are often fielded through short-term projects that are not allowed time to mature, or to permit adequate learning from experience.

Part III summarises the extent of land degradation in the five 'stans', which began with the conversion of vast areas of land to agriculture in the Soviet era, sometimes successfully but rarely sustainably. There are some excellent maps utilising international climate, land use and vegetation datasets. The authors indicate that developing a capacity to monitor resource changes is a complex undertaking and describe remote sensing approaches for this. To this reviewer, some of this treatment is rather theoretical and does not, for example, link future 'ground truthing' to the geo-referenced monitoring points established from the 1960s by the Soviet Desert Research Institute $^{3}$ and available Chinese data, both important in analysing trends and achieving acceptance.

Part IV focuses on the transboundary issue of water and summarizes data on water availability, water use and resulting damage. There is an authoritative discussion of the management of the rivers in the Soviet period and the probably ineffective changes since. There is a summary (Table 10.1) of the technical options to improve irrigation water use efficiency and a second (Table 10.2) listing the institutional and policy-oriented options for action to support improved technologies. A conceptual model discusses the key factors for the future including climate change, the tension between hydropower generation and irrigation needs, the environmental effects of irrigation and water use/over use, water logging and land degradation, as well as the direct (land related) and indirect (water related) measures to address SLM. The discussion demonstrates that it is impossible to effectively achieve SLM by addressing a single factor, for example only land or water, as frequently occurs now.

In Part V, the principal editor places the GCA in a broader context including Iran, Pakistan and India, the Indian Ocean 'Maritime Silk Road', and the current Chinese 'Belt and Road' initiative to re-establish the former 'Silk Road(s)' trade links between East and West. The purpose here is to further justify wide international attention and investment towards solving the socio-ecological problems of GCA. Recounting the history of these geo-strategic events and summarizing the region's resources and the demand for these from China and Europe helps the reader see trends that are not yet prominent in general discourse.

This reviewer suggests that most efforts to address the 'social-ecological' tasks outlined in the book (and the resource needs of surrounding powers) do not sufficiently consider the needs of rural populations that depend on natural resources for their livelihoods, no doubt because of the cost and difficulty of doing so. But success is unlikely any other way. The reviewer also suggests that the transboundary and cross-disciplinary nature of the barriers to SLM are such that 'transformational' institutional policy change is needed, as articulated by Young 4 , a fundamental shift in strategy with strong 'reform champions' at international, national and local levels.

The authors describe many national adaptation strategies that can be tried; some from a natural resource 
management perspective, some from a market perspective and some from an institutional perspective. They emphasis that these initiatives need to be seen through the lens of poverty alleviation if they are to be successful. The problems of land degradation certainly require solutions that embrace ecological requirements such as carbon sequestration, water use efficiency and biodiversity conservation, but they must also concurrently improve livelihoods if they are to be taken up. The inhabitants have solved problems of sustainability in the past ${ }^{5}$ but as a result of poverty, changing socio economic and political circumstances, traditional coping strategies are now insufficient. The authors conclude with a new paradigm for research and technology transfer that requires greater investment but is justified by the international public good that would result from success.

\section{Endnotes}

${ }^{1}$ The book uses the UNESCO definition: the five former Soviet republics (the 5'stans') plus Afghanistan, Mongolia and most of Western China (Xinjiang and the Tibetan Plateau).

${ }^{2}$ The five 'stans' of Central Asia are Turkmenistan, Tajikistan, Kyrgyzstan, Kazakhstan and Uzbekistan.

${ }^{3}$ Described in Babaev A G (Ed.) Desert problems and desertification in Central Asia, (Chapter 2) Springer Berlin Heidelberg 1999. ISBN 3-540-65647-2.

${ }^{4}$ Transformational Change in Environmental and Natural Resource Management: Guidelines for Policy ExcellenceMichael D Young and Christine Esau (Eds.). Earthscan from Routledge (Oxon) 2016. ISBN 9781315715919 (ebk)

${ }^{5} \mathrm{~A}$ review of community activities in SLM in Czarist, Soviet and modern times appears in Annaklycheva J. Dissertation; The Current State of Desertification Processes and the Methods Used to Combat it. Cologne University 2002.

\section{Abbreviations}

GCA: Greater Central Asia; GIS: Geographical information system; LDN: Land degradation neutral; SLM: Sustainable land management

\section{Acknowledgments}

Not applicable.

\section{Author's contributions}

I declare that I am the sole author, and there were no other writing or other services utilised. The author read and approved the final manuscript.

Ethics approval and consent to participate

Not applicable

Consent for publication

Not applicable

Competing interests

The author declares that he has no competing interests.

\section{Publisher's Note}

Springer Nature remains neutral with regard to jurisdictional claims in published maps and institutional affiliations.

Received: 12 July 2018 Accepted: 20 August 2018

Published online: 01 October 2018

\section{Submit your manuscript to a SpringerOpen ${ }^{\circ}$ journal and benefit from:}

- Convenient online submission

- Rigorous peer review

- Open access: articles freely available online

- High visibility within the field

- Retaining the copyright to your article

Submit your next manuscript at $\boldsymbol{\nabla}$ springeropen.com 